\title{
THE ICONIC CHARACTER OF THEOLOGICAL LANGUAGE. THE PHILOSOPHY OF JEAN-LUC MARION AND THE $7^{\mathrm{TH}}$ ECUMENICAL COUNCIL
}

Johannes SOLBERG*

\begin{abstract}
In this paper I will give a short analysis and a critique of the contemporary philosopher Jean-Luc Marion's (b. 1946) interpretation of the $7^{\text {th }}$ Ecumenical Council. Throughout his writings, Marion addresses the iconic theology of the Orthodox Church in order to approach a phenomenological (and post-modern) concept of God, a 'God without being', not bound to the limitations of the ontological difference between Being and beings that characterizes modern metaphysics. Marion admires Heidegger for the onto-theological critique of western philosophy, and against this background Marion's claim is that iconic theology is able to surpass the dichotomy of kataphatic and apophatic theological discourse. In Marion's view, the way to annul the procedure of either affirmation or negation in theological language is to use and understand language pragmatically. In this manner, he intends to propose a theology that does not idolize God as being, and thereby open a third way of theological discourse. To be precise, the theology of the icon is not limited to images alone, but also involves an iconic use of language, that is a language that does not invoke an inherent reference between being and God. Additionally, the pragmatic use of language involves the idea of 'deconstruction', the opinion that the meaning of language is arbitrary and subject to different contexts of use. A proper critique of Marion will be that his concept of 'God without being', is still located inside the ontological difference of Being and nonbeing, and that he in this way does not follow his own interpretation of the iconic theology of the $7^{\text {th }}$ Ecumenical Council.
\end{abstract}

Key words: Iconic theology, onto-theology, phenomenology, language pragmatics, apohatiscism.

* PhD student at Norwegian School of Theology, Oslo, Norway. 


\section{Introduction}

In the $6^{\text {th }}$ century, the iconoclastic crisis haunted the Church. One of the arguments of the iconoclasts was that a true image had to be of same being as its prototype. Iconoclastic emperor Constantine V writes: "[An image] must be consubstantial with the depicted (prototype), so that everything can be safeguarded, otherwise it is not an image" of the Emperor, the icon had to be homoousios with the depicted prototype. Accordingly, the iconoclasts found support in an interpretation of the formula outlined in Colossians 1:15 where St. Paul proclaims that Christ is "the icon [eikon] of the invisible God". As Christ is of the same being as the Father, so has the icon to be of the same being as its prototype. This form of iconoclasm emphasises the very impossibility of the image. However, this interpretation was discarded because of its incoherence with the Christian tradition that differentiates between substantial presence and anamnetic and hypostatical representation ${ }^{2}$. Whereas the decisions of the $7^{\text {th }}$ ecumenical council from the outset was received as a defence of the Tradition of veneration of images, the philosopher Jean-Luc Marion offers a broader interpretation: Marion indicates that the council's decisions have impact on use of language as well.

The philosophical theology of Marion is dedicated to the intersection between the phenomenology of the icon and the philosophy of language. In his writings he draws a clear line between the idol and the icon on the basis of his interpretation of the conciliar definition of Nicea $\mathrm{II}^{3}$. According to Marion, it is not only statues and images that may be

1 Alain, Besancon, The forbidden image. An intellectual history of iconoclasm. Trans. TODD, Jane Marie, University of Chicago Press, Chicago and London, 2000, p. 125.

2 See next footnote, especially the determination of the purpose of representational art as 'remembering' and 'longing' for the prototype. This is what I mean by the term 'anamnetic'. The 7th ecumenical council defines the relation between type and prototype as an anamnesis, contrasting the view of substantial identity.

3 Especially, consider this excerpt of the text of the $7^{\text {th }}$ ecumenical Council: "The more frequently they are seen in representational art, the more are those who see them drawn to remember and long for those who serve as models, and to pay these images the tribute of salutation and respectful veneration. Certainly this is not the full adoration \{latria\} in accordance with our faith, which is properly paid only to the divine nature, but it resembles that given to the figure of the honoured and life-giving cross, and also to the holy books of the gospels and to other sacred cult objects. Further, people are drawn to 
ARS LITURGICA. From the Image of Glory to the Images of the Idols of Modernity

idolatrous or iconic, but language-concepts may also be characterized by the same distinction. An idolatrous use of language may occur in any theological discourse in which the intention is to establish direct control and reference of the language concerning the concept of God. The theological discourse can only be iconic if there is no metaphysical reference between the concepts in use and the reference. In the light of this, adherence to a theory of pragmatic language is the mode of iconic theology ${ }^{4}$.

The pragmatic approach to theological language is dealt with in Marion's book God without Being (1984). Here, Marion argues that the concept of God can only be thought of in an iconic way, outside the ontological difference between Being and beings. On this basis he proposes a concept of God without being.

In this paper, I will (1) analyze Marion's interpretation of the $7^{\text {th }}$ Ecumenical Council as concerning the iconic use of language. Secondly, (2) I will argue that Marion's theology of 'God without Being' is incoherent with an iconic view on language because it reintroduces a clear cut dichotomy of inside and outside, and by this operation indicates a new determination of God from the ground of Being.

\section{Philosophical context and the relation between iconic theology and language}

The immediate philosophical context for Marion's desire to cross out the concept of 'Being' as the ultimate reference characteristic of the concept of God, is Heidegger's determination of western philosophy as 'the onto-theological foundation of metaphysics'. Heidegger regarded the western philosophical tradition as nihilistic, as the question of Being (Das Seinsfrage) was obliterated in it.

For Heidegger, the phenomenological method serves his new emphasis on the importance of the question of Being. Phenomenology is

honour these images with the offering of incense and lights, as was piously established by ancient custom. Indeed, the honour paid to an image traverses it, reaching the model, and he who venerates the image, venerates the person represented in that image." http://www.papalencyclicals.net/ Councils/ ecum07.htm (accessed, 23.03.2017).

4 'Pragmatic language' refers to the view that the given meaning of language relates to our use of language in interactions with others in different contexts. 
identified with ontology in regards to the fact that the totality of phenomena shows itself as $\tau \alpha$ ov $\tau \alpha$ - Das Seiende. 5 To be short; being gives itself to the consciousness of man. This identification of givenness to being also becomes very clear in the German world for 'there is'; es gibt, literally; it is given ${ }^{6}$. Being given unfolds in time and both those connotations are present in what Heidegger mean by using the 'es gibt'.

Heidegger approaches the phenomenology of givenness from a new and critical reading of the history of western metaphysics ${ }^{7}$. Heidegger's claim is that, while metaphysics shaped the understanding of being - or the 'what is', it does as well determine how we understand what 'anything is'. Consequently, metaphysics functions as 'ground' for thinking about being as such, as a justification or legitimation of reason.

Additionally, in the view of Heidegger, it is a characteristic of a metaphysical structure that the truth of the totality of beings per se is contained within it $^{8}$. The possible answers to the question of what being 'is', is circumscribed by the limits of the actual metaphysical rationale. As Heidegger understands the western philosophical tradition, its metaphysical framework is guided by the question: What is that which is? ${ }^{9}$ Heidegger remarks - in correspondence with his understanding of metaphysics claim to be the truth of the totality of being - that this question is two-fold ${ }^{10}$. On the one hand, it is asking about the essence of particular things, what things are. On the other hand, it is asking about the Being of beings, about the totality of beings as such. Heidegger identifies these two parts of the metaphysical question as either ontology or theology ${ }^{11}$. Together, the metaphysical question about being is, therefore, an onto-theological question, with two justifications. To be more precise,

5 Martin HeIDEgGER, Sein und Zeit, M. Niemeyer Verlag, Tübingen, 2006, (7a) p. 28

6 Ibidem, p. 230.

7 Martin Heidegger, Gesamtausgabe, Seminare Vol. 15., Ed. Edward, C., Klostermann Verlag, Frankfurt, 1986, p. 337.

8 D.F., Krell, Nietzsche, The will to power as Knowledge and as Metaphysics, trans. Stambaugh et. al., Harper and Row, New York, p. 187. I. THOMSON, "Reference from Ontotheology? Understanding Heidegger's Destruktion of Metaphysics”, in International Journal of Philosophical Studies, no. 3/2000, p. 297-327.

9 Martin HeIDEGGER, Sein und Zeit, p. 28.

10 IDEM, "Kants thesis about being", Trans. Klein and Pohl., in Southwestern Journal of Philosophy, no. 3/1973, p. 7-33.

11 Look to "Kants thesis about being", p. 10 and following. 
the ontological side of this question, ask for the Being (Das Sein) that all beings (Das Seiendes) have in common. The theological side asks of the highest Being, the most supreme and perfect Being, the 'causa sui', the first mover. Consequently, the concept of 'God' is metaphysically circumscribed, and at the same time the notion of the divine legitimates the metaphysical construction. This double justification is inherent in the term onto-theo-logy. In the light of this, Heidegger argues that theology can only be true to itself if it separates itself from philosophy, and especially ontology.

The process of thinking brings Being to language and concepts, making language 'Haus des Seins'12. This process consists in thinking and formulating thoughts with language 13. Due to this, being is the very essence of thinking, and the meaning of Being the essence of language. By language here, Heidegger does not only mean the daily (vulgar) language, but language formulated as a reflection of the giving of being itself $^{14}$.

Marion's philosophy is an attempt to make serious Heidegger's claim that western metaphysical tradition, particularly the metaphysics of presence in language, will have to be abandoned as an approach in theological discourse. In Marion's theological works, Heidegger's insights are merged with Traditional iconic theology.

In the traditional iconographic tradition of the holy images, the honor given to the icon passes on to the one depicted ${ }^{15}$. The model for this kind of theological iconography is the incarnation, as Christ is viewed upon as the visible icon of the invisible Father (Col. 1:15). According to

12 Martin HeIDEgGer, "Letter on Humanism”, trans. F.A. CAPUZZI, in Pathmarks, McNeILL, W., (ed.), Cambridge University Press, Cambridge, 1998, p. 239

13 Martin Heidegger, Letter on Humanism, p. 239 : "Language is the house of being. In its home human beings dwell. Those who think and those who create with words are the guardians of this home. Their guardianship accomplishes the manifestation of being insofar as they bring this manifestation to language and preserve it in language through their saying. Thinking does not become action only because some effect issues from it or because it is applied. Thinking acts insofar as it thinks." In addition to this, one may add a reference to Heidegger"s book Unterwegs zum Sprache, Pfullingen, 1959, p. 220, where he writes about the Da-sein as pronouncing itself in language.

14 Martin HeIDEgGer, Letter on Humanism, p. 249.

15 The seven ecumenical councils, ed. P. SCHAFF / Mace H., Eerdmans / T \& T Clark, Michigan, reprinted 1997, p. 550. 
Marion, this paradox visibility/invisibility demands Christian theology to pay attention to the revelation of the distance between God and the created realm. If the distance is ignored, confused or at worst abandoned, theology will eventually function as an idol, which primary idea is to adapt the concept of God to a given structure of philosophical discourse. Consequently, if Being is the essence of the meaning of language, and if the aim is an univocal fixed reference between the concept of God and God, an onto- theological discourse does not reveal the divine at all, but presents man to an idol.

In light of this, Marion indicates that the theological discourse can only be iconic if the language is used pragmatically ${ }^{16}$. Contrary, the theological discourse functions as an idol if its aim is to fix an absolute reference between the Being and God. In this case, theology becomes onto-theology, and God is treated as Being, either as ultimate Being, absolute Being or as the Causa Sui (the first mover).

Henceforth, Marion's phenomenology of the idol and icon is strongly related to the philosophy of language. The question in the context of a theological discourse is whether language-concepts are considered metaphysically connected to its referents or arbitrarily different and dependent on context. It is thus a question of how one reads or understands the text, exactly in the same way as the gaze of the believer constitutes the piece of art either as idol or icon. The distance between icon and prototype may, therefore, be considered to be the same distance that characterizes the difference between concept and referent.

Marion highlights the difference between the idol and the icon as "a conflict between two phenomenologies"17. The difference lies in the manner in which the object appears to the believer, as two distinct "modes of apprehension [or reception] of the divine invisibility"18. The idol functions as a mirror that reflects the gaze of the believer, in the way that

16 That language is used pragmatically in an iconic theology, is a clear presupposition throughout Marion's work. Look to MARION, "In the name. How to avoid speaking of Negative Theology", in J.D CAPUTO (ed.), God, The Gift and Postmodernism, Indianapolis, Scanlon, Indiana University Press, 1999, p. 46 and in R. HORNER/Jean-Luc MARION, A theo-logical introduction, Aldershot, Ashgate Publishing, 2005, p. 94.

17 Jean-Luc Marion, God without Being, trans. Carlson, T., Chicago, Chicago University Press, 1984, p. 7.

18 Ibidem,p. 9. 
it is a presentation not of the divine, but of the intention of one who sees: "Name your Idol, and you will know who you are. What I look at that is visible decides who I am. I am what I can look at. What I admire judges me. There is therefore no reason to oppose aesthetics too sharply to ethical responsibility"19. We see clearly that Marion proposes an understanding of the difference between idol and icon as 'a manner of being' ${ }^{20}$, and not in being two different categories of being. The same object may function as both idol and icon. The difference lies in the mode of respectively adoration or veneration, or more precisely the manner of apprehension of the divine in the object venerated. In this way, the idol does only resemble the divine as far as it fits the already set structure of human gaze and experience.

To clarify the distinction between idol and icon, Marion likens his pragmatic view on language to the traditional terminology of ousia and hypostasis $^{21}$. As known from Orthodox tradition, ousia designates the substantial presence, and hypostasis the particular characteristics of a person or even an object. The visibility and characteristics of a person is due to his particular hypostasis, and not to the ousia, which is a generic term $^{22}$. In the icon, the ousia is not present. The presence is due to the likeness of the depicted, and the absence is due to the substantial emptiness of this likeness. In an idol, on the other hand, the divine is kept inside the borders of the gaze of the believer and henceforth inside the boundaries of this believer's system of thought. The idol does, therefore, present the believer his own thoughts and his own image of the divine. In this manner, the distinction between substantial presence and personal presence is blurred. Accordingly, to subordinate God to Being is for Marion to gaze upon Being as an idol through which we claim to see a portion of the true invisible God.

Whereas human intention and gaze determine the idol, the icon causes contemplation of the intention and gaze of the invisible. In this

19 MARION, J-L, In Excess, trans. R. Horner/R. BERRAUd, New York, Fordham University Press, 2002, p. 61.

20 Ibidem, p. 7-8.

21 Ibidem, p. 18.

22 St. Basil the GReat, "Letter 214", in Nicene and Post-Nicene Fathers, Vol. 8. Edited by SCHAFF, P. and WACE, H., New York, Christian Literature Publishing Co., $1895^{2}$. 
way, the intention meets the believer, not otherwise ${ }^{23}$. In the same manner, the referent of the icon (the invisible) slips away from any definition, as it exceeds all language and concepts ${ }^{24}$. Consequently, the icon invites the distance of infinite depth to its referent. This distance is to be understood as infinite and thus ultimately indeterminable by any concept. Henceforth, Marion emphasises that "the gaze makes the idol, not the idol the gazewhich means that the idol with its visibility fills the intention of the gaze, which wants nothing other than to see"25. The idol presents to the beholder's gaze his own intention, so what he sees is the reflection of his own gaze.

The icon phenomenologically inverts this idolatrous operation. The gaze does not determine the icon, but 'provokes' it towards a vision unaccountable within its own $\operatorname{aim}^{26}$. In this way Marion turns around the iconoclastic Emperor's statement that a true image has to be of the same being as its prototype. In the icon, St. Paul's formula rendering Jesus the 'icon of the invisible God' becomes paradigmatic because the icon does not present the visible as a means of discerning between visible and invisible, offering an image for the grasp of the gaze. Instead, the icon presents the invisible precisely as invisible; as that which confronts the gaze without becoming an object for the determination of the gaze.

The privileged reference here is the face; because the gaze and aim that determine the icon as the icon are not those that belong to the one who apprehends the icon, but to the icon itself as a presentation of the invisible ${ }^{27}$. So, while the idol's reflexive origin admits a fixed point of return, the icon can be submitted to no measure, it is infinite in its excessiveness.

Marion's notion of phenomenology is based on the 'unconditional given', a phenomenology that rests on the Giver of the given ${ }^{28}$. This

23 J.L. MARION, God without Being, p. 18-19. 'Intention' has to be understood phenomenologically in this context. In phenomenology, intention refers to the fact that our consciousness is always directed towards something.

24 Ibidem, p. 23.

25 J.L. MARION, God Without Being, p. 10.

26 Ibidem, p. 17.

27 Ibidem, p. 20-21.

28 J-L. MARION, Being Given, trans. KOSKY, J.L., Standford, Standford University Press, 2002 , p. 4. 
reduction of the subject as the active part in the experience of the world renders open the thought of the totally transcendent Other. The experiencing subject, the Ego, cannot give itself the identity of constructing its own consciousness. In the light of this, Marion constructs an argument that says that the unconditional given requires a giver, and that this giver is God, who gives in love ${ }^{29}$. A phenomenology based on the unconditional given, will therefore imply the Christian revelation of a God that is love, and a God that loved man first (1. Joh. 4:10).

\section{The unconditionally given: Mystical theology and language pragmatics}

In the light of the phenomenology of the unconditionally given, Marion consider the history of metaphysics and onto-theology, as a history of the idol. The onto-theological constitution, in which the metaphysical concept of God belongs, is idolatrous because it intends to make God 'at hand' to the philosophers, to justify their methods ${ }^{30}$ Here, Marion is totally in line with Heidegger's rejection of the constitution of metaphysics as onto-theology.

Marion purpose then, is, as mentioned above, to develop a phenomenology of the 'unconditional given', which does not determine any conditions for the gift ${ }^{31}$. Being unconditional means that we cannot comprehend the distance in which the gift is given: "The unthinkable, as the distance of Goodness, gives itself - not to be comprehended but to be received" 32 . As Marion points out, divine generosity itself know no limits, and, therefore, the limitations of its appearance is due to our finite reception of it, and not to God's giveness ${ }^{33}$. The essence of the unconditionality is therefore, immeasurable and infinite.

This gift of divine revelation is given in love, a love that "dissolves the tie that ties it to our thought" $"$. Henceforth, it is only the divine gift of

29 J.L. MARION, The Erotic Phenomenon, trans. LEWIS, S., Chicago, University of Chicago Press, 2007, p. 222.

30 'Methaphysics produces a limited concept of «God' that it wrongly wants, in turn, to equate fully or adequately with God himself". J-L. MARION, Being Given, trans. KOSKY, J.L., Standford, Standford University Press, 2002, p. 10.

31 Ibidem, p. 4.

32 J.L. MARION, The Idol and Distance, p. 155.

33 Ibidem, p. 158.

34 J.L. MARION, The Idol and Distance, p. 141. 
love that is able to free thinking from thinking inside the dichotomy of the ontological difference of Being and beings. Marion's phenomenology is an attempt to think in a non-metaphysical mode, as far as phenomenology is a question of showing and not rational proving.

As we have seen above, Heidegger's phenomenology puts emphasis on the fact that the phenomenon shows itself. According to Marion, to show itself, the phenomenon has to give itself first: "Only a phenomenology of givenness can return to the things themselves because, in order to return to them, it is necessary first to see them, therefore to see them as they come and, in the end, to bear their unpredictable landing" 35 . Hence, for Marion givenness crosses the phenomenality of the ontological difference, and enables man to receive and experience phenomena 'as they come', given by the ultimate lover and giver, God.

It is clear that Marion understand the conciliar definition of the $7^{\text {th }}$ Ecumenical Council as a determination of two ways to theologize. Says Marion: "When a philosophical thought expresses a concept of what it then names 'God', this concept functions exactly as an idol"36. Marion claims that the "death of God" in modern philosophy, is not the death of the living transcendent God of faith, it is the death of the idolatrous concept of "god", the god of the onto-theological constitution of metaphysics ${ }^{37}$. The metaphysical concept of God is dead, accordingly, and theology can only be saved when it is separated from the ontological difference. The question is whether it is possible to think outside this difference, on the condition that thought and being is interwoven through language.

For Marion, the phenomenology of the given designates the theological language as either idolatrous or iconic. Traditionally, theological language has been divided into cataphatic and apophatic. Marion points out that these two ways of theology fall into the same abyss of ontic reference. Negative theology is affirmative theology inside-out,

IDEM, Being Given, p. 4 We must add here, to be more precise, that «seeing' in this regard does not refer to a «priority of vision' for Marion: "The so-called priority of vision, therefore, becomes decisive only once we miss the privilege of the apparition of the thing itself at the heart of its (sensible, perceptible, «subjective' etc.) appearance - the sole truly decisive matter"; Ibidem, p. 8.

36 IDEM, God Without Being, p. 16.

37 IDEM, The Idol and Distance, p. 15. 
as Marion emphasises: "Negation itself submits its very own operation"38. This means that as long as language is predicative, it does re-inscribe God to metaphysical presence, connected to the 'ousia' of language. ${ }^{39}$ As far as language describes God as Being, it makes Him present to thought and present to language ${ }^{40}$. As we have seen, Marion approach this distinction with what he calls 'the third way' of theology, that is the way of language pragmatism (which he also calls 'the mystical way') which he also calls the mystical way. With the pragmatic view on language he claim to have deconstructed the identification between language and being ${ }^{41}$.

To be more precise on how Marion's phenomenology of the idol and the icon relates to language, it may be useful to cite at some length what Marion says about the three ways of theology:

"[...T] here are three ways of speaking about God [affirmative, negative and pragmatic- mystical], but the difficulty is to understand how it is possible to say that there is a third way. According to the metaphysical theory of discourse, there are only two possible ways. So what exactly is the meaning, the status, the legitimacy of the third way? The point is not whether there is a third one, but how to understand that the third one remains rational, although it does not remain confined to the possibilities opened by metaphysics. My answer would be that the only way to understand the third way, beyond affirmation and negation, without coming back implicitly or explicitly to affirmation is to take seriously the pragmatic use of language" 42 .

God presents himself through language, but God's presence can never be fixed as a metaphysical 'truth' as part of a logocentric system of reference. Additionally, Marion takes the Aeropagite as witness for the possibility for a third way of theological language: '[...] for the perfect and unique cause of all things is above every assertion [ن $\pi \dot{\varepsilon} \rho \pi \tilde{\alpha} \sigma \alpha v \theta \varepsilon \dot{\varepsilon} \sigma v$ ] in the same way as what surpasses the total suppression of all things and and claims to produce itself as a referent".

41 IDEM, God Without Being, p. 23.

42 IDEM, "In the name", in CAPUTO and SCANLON (eds.), God, the Gift and Postmodernism, 1999, Bloomington and Indianapolis, Indiana University Press, p. 46. 


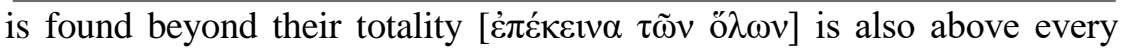

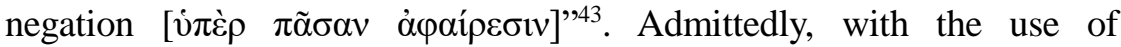
Dionysius, Marion claims that God is above and beyond every affirmation and negation, and that theology has to surpass this dichotomy.

Further on, Marion continues: "The most elevated names (and the ones that are most theological, most directly concerned with the formulation of the Trinity itself) are in this way disqualified without looking back, without remorse" 44 . In this context we should ask whether it is possible to think and use language when it comes to the concept of God, and how to avoid the metaphysics of presence in speaking of Him.

\section{To think 'God' without being}

As seen, for Marion the answer to the question above lies in the alternative to affirmative and negative theology; language pragmatics. A pragmatic view on theological language implies that one uses language on the condition that no statement or utterance can or should be understood meaningfully apart from the context in which they are used, but; "It is a matter of being exposed in one's intending a non-object, exposed to the point of receiving from this non-object determinations that are so radical and new that they speak to me and shape me far more than they teach and inform me" 45 . When the divine is no longer an object for my thoughts to understand, it is no longer my intention alone which constitutes the relation. It is, like the icon, a counter-perspective as well, as ' $\mathrm{I}$ ' is looked upon from the crossing of the infinite distance. When the gaze of the believer is fixed on the face of Christ in the icon, the gaze of Christ will fall back on the believer, and by this invite to contemplation and prayer ${ }^{46}$. This process, the 'contre-regard'47, is a displacement of the strict distinction between object and subject. This opens the possibility of intersubjectivity in Marion's philosophy ${ }^{48}$. Marion replaces the simple subject - object relation with the thought of a counter - intentionality (fr. contre-

43 J-L. MARION, In Excess, p. 135. Reference from Divine Names, VII, 3, 869d-872a; MT I, $2,1000 \mathrm{~b}$ and $\mathrm{V}, 1004 \mathrm{~b}$.

44 Ibidem, p. 138.

45 Ibidem, p. 148.

46 J.L. MARION, Being given, p. 215, 251.

47 IDEM, God Without Being, p. 23.

48 IDEM, Le Visible et le Révélé, Paris, Les Éditions du Cerf, 2005, s $111 \mathrm{f}$. 
intentionnalité) or a reversed intentionality.

This kind of pragmatic mystical theology is lived out in the shape of praise and liturgy. Marion points to the fact that; "with praise, it is no doubt no longer a matter of saying but of hearing [... ""49. About the form of the liturgical praise, one may say as one does about the icon of Christ, that it is not made by human hands. It is a revelation of counter-intentionality, of the God which dwells among men and gives himself hypostatically in language and images, and substantially in the non-likeness of bread and wine ${ }^{50}$. Consequently, God gives himself both substantially and personally, but in two different liturgical operations or directions.

More precisely, Marion indicates that the real problem with the substantial theory of language, is the logic that says that "an essential distinction follows from a nominal one" ${ }^{51}$. It is therefore not the nature of things that follows the names, but the names that follow the categories of the things. This blurring of substance and nomination is at it seems an assault on the doctrine of the consubstantiality of the Trinity. For, according to Marion, the heretics or idolaters, holds that God's "substance is the very same that which is signified by his name" 52 . In Christian doctrine, however, the names are found after the things.

In light of this, Marion proposes the paradoxical statement that God may be known only as not being known ${ }^{53}$. Our problem here - how to think God without being- is therefore strongly connected to the realisation that we do not know God by nature. To not know is to recognize incomprehensibility as the closest one get to a definition of the concept of God. God is not to be determined or submitted to human reasoning. Consequently, our thoughts and language of God are an experience of his absence in distance. On the contrary, substantial presence is to be found in the Eucharistic celebration.

49

50 For the distinction between hypostatical likeness and substantial presence as non-likeness, look to J.L. MARION, God Without Being, p. 166. See as well to p. 182: "In prayer, only an «explanation' becomes possible, in other words, a struggle between human impotence to receive and the insistent humility of God to fulfil".

51 ST. BASIL, "Against Eunomius II, 4", in PG 29, 580b, quoted by J.L. MARION, In Excess, p. 153.

52 Ibidem, p.153.

53 Ibidem, p. 154. 


\section{Critical remarks on Marion's 'without'}

As we have seen, Marion reads Heidegger against Heidegger in order to displace the 'ontological difference' as the primary philosophical theme. The goal with this displacement is a theology of 'God without being', a God that loves first. This means that God is not determined by being, and being is not the fundamental and proper name for God. Being is thus a gift of God bestowed upon beings and not the 'ground' for the concept of 'God'.

Although Marion reads Heidegger critically, by replacing 'being' with 'love', he intends to follow Heidegger in his understanding of the relation between philosophy and theology ${ }^{54}$. Marion claims that the word 'Being' must not intervene in a theological discourse which consequence is that theology must free itself from the metaphysical tutelage to philosophy and frees it to envision a free God who acts out of love and gives being in revelation ${ }^{55}$. Hence, God must be thought of as 'without being'.

On the other hand, by saying that God is 'without' being, I will argue that he is actually employing a metaphysical language system which are given meaning only in relation to other meanings that are to be suppressed, as is the case with the 'with' or 'without' dichotomy. In the sphere of deconstructional criticism, the concept of God and the relation between language and aesthetics may be thought of otherwise, since if God may be 'without' being, he may also be 'with' or 'within' Being. ${ }^{56}$ The question is how Marion is able to establish such a predicate and what becomes its implications. The first implication of the 'without' is obviously that this statement presupposes a stable difference between the

54 This interpretation of Heidegger has recently been contested by PuNTEL, L., Being and God, trans. White, A., Evanston, Northwestern University Press, 2011 p. 304: “[...] postmodern authors tend to quote only those passages from Heidegger's writings in which he speaks of the necessity of overcoming metaphysics. This leads to crass misinterpretations of Heidegger's thought." I find this critique very relevant and interesting. However, for the sake of my argument here, I will stick to Marion's interpretation.

55 J.L. MARION, God without Being, s. 63.

56 'Otherwise' does not connote 'outside' in this context, because deconstructional criticism erase the dichotomy of 'inside' and 'outside'. It is therefore not possible to just think 'outside' the metaphysics of the ontological difference. 
two poles of identity and difference ${ }^{57}$.

As we have seen, Marion suggests that the phenomenology of the icon should be predominant when it comes to theology. We should therefore not fear to read Marion's texts reflexively, as an iconic text. Additionally, the icon does not yield any metaphysical presence but referring the beholder to the face of the prototype. One of the important dichotomies in the metaphysical and logocentric view of language is the difference between inside and outside. To say that God is 'without' being is to say that God is outside the language of Being, or even -aestheticallyoutside the frame of Being. Henceforth, we will have to ask if the concept of 'without' is possible to maintain in a theology of pragmatic absence.

To put the question in another way: Is it possible to make a cleancut line between the icon and the process of writing theology, within the frame of iconic phenomenology? Is it not a relation between the question about the distinction between the 'without' and the 'within' and the impossible distinction between text and context? Following the deconstructional backdrop of linguistic pragmatism, it seems impossible to determinate this dichotomy, neither between text and context, nor between aesthetics or epistemology, or 'without' and 'within'.

In the light of this, we see that the aesthetics of iconic theology cannot be judged from the perspective of the 'without' because the thought of a 'without' is dependent on a structure that presupposes the whole set of clear-cut dichotomies in the first place. If the metaphysical structure of those dichotomies is deconstructed, it is not possible to defend a separation between aesthetic theory and the 'without' either. In my opinion, the concept of a God without being seems to be problematic and has to be discussed thoroughly.

What Marion seems to do, especially in regard to the concept of 'God without being', is to separate one meaning from another. By so doing, he establishes a hierarchy of concepts, in which one concept is prior to another and may be interpreted in relation to the meaning of the other concept. Henceforth, Marion's insertion of the 'without' throws

57 Derrida, who is one of the main influences of Marion, has thoroughly deconstructed the dichotomy of identity and difference in the sphere of language. Look to J. DERRIDA, "How to avoid speaking: Denials' trans. Ken Frieden in H. COWARD and T. FORSHAY (eds.), Derrida and negative theology, New York, Suny Press, 1992, p. 127. 
'God' back into the dichotomies of the ontological difference, away from the iconic form of theology. Consequently, in my opinion, this little world alone is a key that opens the gates for the metaphysics of presence to once again enter theology, and thereby makes is a new form of negative theology that is no more than an affirmative theology upside-down.

Consequently, Marion's notion of the 'without', and its conceptual frames ${ }^{58}$ of inside and outside, is in this way yielding new space for metaphysics ${ }^{59}$, because the meaning of the concept of God is defined in relation to 'what its not'. The frame as a border between 'what is' and 'what is not', seems, therefore, to be necessary for Marion's system of thought, since the concept of God is the very core of his theological critique of onto-theology. In the light of his criticism of onto-theology and its implications, I find this to be inconsistent.

Further, I find that the structuring limits of the 'without' does suspend the iconic phenomenality, by the presupposition that the canopy of reason delivers a universal and autonomous interpretation and control by the dichotomous use of language as metaphysics: The concept of God is forced to be 'without'. According to a pragmatic theory of language, it is impossible to make a clear cut between what is and what is not, because language cannot refer directly and objectively to 'beings'.

One consequence of the deconstruction of the metaphysical dichotomy between 'within' and 'without' is that one cannot determine whether God is 'within' (!) being or 'without' being. It is not possible to determine the concept of God in this way, with this or other concepts. It is, in the light of the deconstruction of the metaphysics of presence, only possible to talk about God as without something, if this 'without' is meant as way of speech, without deterministic pretensions ${ }^{60}$. In other words; we

58 The relation between frame and concept relies on the fact that the concept functions as a frame when it separates one meaning of a word from another, it is a border between different meanings. In other words, the concept is a frame that contains a certain meaning used in a particular context.

59 I use the world 'metaphysics' as do Marion. That means it is very undifferentiated.

60 If so, we may ask what is the meaning of speaking of God without being after all. Derrida, who influenced Marion on his view of language as pragmatic, seems to mean that it necessary to use language in as if it is a logical and defined connection between the referent and what is referred to. Or, in his own saying; "there is frame, but the frame does not exist". In the same way, we may say that God is, but He is not. Look to J. DERRIDA, 
experience 'the real as if it is real, although the pragmatic use of language does not allow such reference ${ }^{61}$. The 'without' belongs to the terminology of the 'pure cut', that is a metaphysics that functions as 'ground' for the very dichotomy that Marion tries to escape.

Finally, as seen above, Marion claims that the difference between idol and icon is 'a manner of being' 62 , and not in being two different categories of being. As I understand this, the concept of Being, as well as the ontological difference, may be considered idolatrous but on the other hand it may also be interpreted iconic. As Marion himself has claimed; words themselves gain meaning not from a fixed metaphysical reference outside our daily use, but from the context in which they are uttered and understood. Conclusively, the context of theology is the Church, and the words are there elevated to a higher meaning, due to their use in the liturgical action and prayer. So also with the concept of 'Being'.

\section{References}

1. BesAnCON, A, The forbidden image. An intellectual history of iconoclasm. Trans. TODD, Jane Marie, University of Chicago Press, Chicago and London, 2000.

2. DERRIDA, J, The truth in painting, trans. Bennington, G., and McLEOD, I., University of Chicago Press, Chicago, 1987.

3. DERrIDA, J., "How to avoid speaking: Denials" trans. Ken Frieden in Derrida and negative theology, ed. Coward, H. and Forshay, T., New York, Suny Press, 1992.

4. HeIDEgGer, M., Sein und Zeit, M. Niemeyer Verlag, Tübingen, 2006.

5. HeIDEGGER, M., Gesamtausgabe, Seminare Vol. 15., Ed. Edward, C., Klostermann Verlag, Frankfurt, 1986.

6. KRELL, D.F., Nietzsche, The will to power as Knowledge and as Metaphysics, trans. Stambaugh et. al., Harper and Row, New York, 1987.

The truth in painting, trans. Bennington, G., and McLeod, I., Chicago, University of Chicago Press, 1987, p. 81.

61 Instead of a quick trip back to metaphysics, "deconstruction must neither reframe nor dream of the pure and simple absence of the frame. These two apparently contradictory gestures are the very ones - and they are systematically indissociable - of what is here deconstructed", Ibidem, p. 73.

62 J.L. MARION, God without being, p. 7-8. 
7. HeidegGer, M., "Kant's thesis about being", Trans. Klein and Pohl. Southwestern Journal of Philosophy, 4 (3), 1973.

8. HeidegGer, M., "Letter on Humanism", trans. CApuzzi, F.A., in Pathmarks, ed. McNEILL, W., Cambridge University Press, Cambridge, 1998.

9. Horner, R., Jean-Luc Marion, A theo-logical introduction, Ashgate Publishing, Aldershot, 2005.

10. MARION, J-L., The Erotic Phenomenon, trans. LEWIS, S., University of Chicago Press, Chicago, 2007.

11. MARION, J-L., Le Visible et le Révélé, Paris, Les Éditions du Cerf, 2005.

12. MARION, J-L, In Excess, trans. Horner, R./Berraud, V., Fordham University Press, New York, 2002.

13. MARION, J-L, Being Given, trans. Kosky, J.L., Standford, Standford University Press, 2002.

14. MARION, J-L., "In the name. How to avoid speaking of Negative Theology", in God, The Gift and Postmodernism, J.D. Caputo (ed.), Indiana University Press, Indianapolis, 1999.

15. MARION, J-L., God without Being, trans. T. Carlson, Chicago University Press, Chicago, 1984.

16. PunTEL, L., Being and God, trans. A. White, Northwestern University Press, Evanston, 2011.

17. St. BASIL THE GREAT, "Letter 214", in Nicene and Post-Nicene Fathers, Second Series, Vol. 8. P. Schaff and H. Wace (eds.), Christian Literature Publishing Co., New York, 1895.

18. St. John Of Damascus, On the divine images, trans. D. Anderson, Crestwood, New York, St. Vladimirs Seminary Press, 1997.

19. ThOMSON, I., "Reference from Ontotheology? Understanding Heidegger's Destruktion of Metaphysics", in International Journal of Philosophical Studies, no.3/2000.

20. The seven ecumenical councils, P. Schaff and H. Mace H. (eds.), Eerdmans / T \& T Clark, Michigan, reprinted 1997. 